PART 5

Poland and Sweden 
Kristoffer Neville - 9789004378216

Downloaded from Brill.com04/26/2023 01:00:46AM via free access 


\title{
History and Architecture in Pursuit of a Gothic Heritage
}

\author{
Kristoffer Neville
}

In the sixteenth and seventeenth centuries, Gothicism, or a self-identification with the ancient Gothic people, was a deeply important phenomenon. This drew on fairly diffuse medieval traditions, but took concrete form in a series of historical works produced in the sixteenth century, most specifically a chronicle by Johannes Magnus, which was complemented by a more anecdotal history produced by his brother, Olaus. ${ }^{1}$ The brothers were Catholic exiles living in Rome, and although they produced their works there for an Italian audience, the impact of their books was greatest in Northern Europe, where new editions soon appeared for an eager audience. Johannes Magnus's text, which became the fundamental modern basis for all subsequent iterations of the idea, traces the Goths, generation by generation, from the sons of Noah to modern rulers - the kings of Sweden, in his case, although other authors produced variants that traced these Gothic ur-ancestors to other princes. ${ }^{2}$ This offered an unsurpassable antiquity to one's ancestry, and with it tremendous prestige.

The ancient lineage was enhanced by the Goths' great feats: their defeat of the Romans in the fifth century gave them an unmatched reputation for strength and power that was presumed to be still present in their descendants, if latent. King Gustaf II Adolf of Sweden's exploits in the 1630s against the Habsburg Holy Roman Emperors - who claimed a direct lineal descent from the ancient Roman emperors (and also, remarkably, from the Goths) - were

1 Magnus Johannes, De omnibus Gothorum Sveonumque regibus (Rome, Ioannes Maria de Viottis: 1554); Magnus Olaus, Historia de gentibus septentrionalibus (Rome, Ioannes Maria de Viottis: 1555), trans. as Description of the Northern Peoples by P. Fisher and H. Higgens, 3 vols. (London: 1996-1998). See Johannesson K., The Renaissance of the Goths in Sixteenth-Century Sweden. Johannes and Olaus Magnus as Politicians and Historians, trans. J. Larson (Berkeley - Los Angeles: 1991); Santini C. (ed.), I fratelli Giovanni e Olao Magno. Opera e cultura tra due mondi (Rome: 1999).

2 del Castillo Julian, Historia de los reyes godos que vinieron dela Scitia de Europa, contra el Imperio Romano, y a España: y la succession dellos hasta el Catholico y potentissimo don Philippe segundo Rey de España (Burgos, Philippe de Iunta: 1582).

(C) KRISTOFFER NEVILLE, 2019 | DOI:10.1163/9789004378216_023

This is an open access chapter distributed under the terms of the prevailing CC-BY-NC-ND License at the time of publication. 
often compared to the late-antique Gothic defeat of the Romans. ${ }^{3}$ Although this narrative was essentially imagined, it carried great value, and played a role comparable to the resurrection of the ancient Batavians in the Netherlands, the Sarmatians in Poland and Hungary, and other comparable origin myths that were fundamental to the standing of these lands and of their ruling elite. ${ }^{4}$

The Gothic discourse was vibrant in part because it took a deeply polemical edge. The heritage was shared and contested by groups across a wide geographical area, including some with longstanding animosities. Sweden and Denmark were hereditary rivals and enemies, but both claimed descent from the Gothic tribes. Spain, which also claimed Gothic origins, was not a regional rival of the Scandinavian kingdoms, but was separated by confession and the deep divisions stirred by the Thirty Years' War (1618-1648). Many historians also associated places in and around the Holy Roman Empire with Gothic origins. The debates were about both lineage and geography, which frequently became entwined. The disputes were not so much about which group or land could claim descent from the Goths, but rather about which was most directly descendent, or which land was the original, and thus most ancient, home of the Goths. ${ }^{5}$

Although it was hardly alone in claiming this heritage, the Swedish court was particularly inventive and aggressive in its historical arguments that the kingdom was the homeland of the Goths, and its kings their most direct descendants. As a newly rich military power, it used this material to create a long and important history for itself that otherwise was conspicuously lacking.

Demonstrating this history was a challenge, however. Both the early sources and the modern literature are largely concerned with text. Architecture is marginal in this historical discourse, and has remained largely absent in the modern literature on the topic. Nonetheless, many publications concerned with Gothicism give some attention to the historical study of buildings, and these passages play a substantial role in demonstrating aspects of the Gothic narrative that were not easily proven through texts. The elaboration of this introduced an early and unfamiliar strand of writing on architectural history that expands our idea of the scope and methods of the early literature

3 Zellhuber A., Der gotische Weg in der deutschen Krieg. Gustav Adolf und der schwedische Gotizismus (Augsburg: 2002).

4 For a recent introduction with further references, see Geary P., "Europe of Nations or the Nation of Europe: Origin Myths Past and Present", Revista Lusófona de Estudos Culturais / Lusophone Journal of Cultural Studies 1 (2013) 36-49, and the essays in this volume.

5 Schmidt-Voges I., De antiqua claritate et clara antiquitate Gothorum. Gotizismus als Identitätsmodell im frühneuzeitlichen Schweden (Frankfurt: 2004); Neville K., "Gothicism and Early Modern Historical Ethnography", Journal of the History of Ideas 70 (2009) 213-234, both with references to earlier literature. 
on architecture. These publications are very different from the more familiar column books, biographies of builders, and technical manuals that make up much of the early literature on architecture. They are closer to the antiquarian tradition of Giovanni Pietro Bellori and others, but the arguments are freighted with an ideological presentation of history that is most familiar in the publications of Giovanni Battista Piranesi from the middle of the eighteenth century. ${ }^{6}$ Piranesi's often tortured polemics over the origins and development of ancient architecture are an appropriate reference here, for in his arguments from around 1700 we find an equally revisionist interpretation of history, based in part on architectural history.

\section{History and Architecture}

The essential source for the Gothicist arguments was Jordanes's Getica, compiled in the sixth century AD. This was based on a longer, lost work by Cassiodorus, a Roman consul and minister under the Gothic king Theodoric. Along with the works of Tacitus, Pliny, and other ancient writers, it was parsed for any shred of information it might yield on the ancient north. ${ }^{7}$ All of these ancient authorities were complemented by medieval writers, such as Saxo Grammaticus, who in the decades around 1200 wrote a chronicle of the Danish kings. ${ }^{8}$

There were efforts to pursue other sources and methods as well. Among these were antiquarian studies focusing on the material legacy of these peoples. In 1689-1694, the Swedish crown sent Johan Gabriel Sparwenfeld on a long journey around the Mediterranean to search for evidence or relics of the

6 Bell J. and Willette T. (eds.), Art History in the Age of Bellori. Scholarship and Cultural Politics in Seventeenth-Century Rome (Cambridge - New York: 2002); Kantor-Kazovsky L., Piranesi as Interpreter of Roman Architecture and the Origins of his Intellectual World (Florence: 2006).

7 The Gothic History of Jordanes, trans. C.C. Mierow (Princeton: 1915). See inter alia Goffart W., The Narrators of Barbarian History (A.D. 550-80o): Jordanes, Gregory of Tours, Bede, and Paul the Deacon (Princeton: 1988) 3-111; Søby Christensen A., Cassiodorus, Jordanes and the History of the Goths. Studies in a Migration Myth (Copenhagen: 2002). For the reception of Tacitus in the north, see Schellhase K.C., Tacitus in Renaissance Political Thought (Chicago: 1976) 50-65; Krebs C.B., Negotiatio Germaniae: Tacitus' Germania und Enea Silvio Piccolomini, Giannantonio Campano, Conrad Celtis und Heinrich Bebel (Göttingen: 2005).

8 Saxo Grammaticus, Gesta Danorum, 2 vols, ed. J. Olrik and H. Ræder (Copenhagen: 1931-1957); Saxo Grammaticus: The History of the Danes, Books I-IX, ed. H.E. Davidson, trans. P. Fisher (Cambridge: 1996). See Skovgaard-Petersen K., Historiography at the Court of Christian IV. Studies in the Latin Histories of Denmark by Johannes Pontanus and Johannes Meursius (Copenhagen: 2002). 
Goths. His efforts were only partially successful. He returned with many new publications on the subject, but few archival or antiquarian discoveries. ${ }^{9}$

More routinely, there were excavations and reconstructions of local monuments. Rune stones were studied especially closely, and were valued both for their inscriptions and as objects. The stones were regarded as tangible evidence of a lost antiquity for which there were few other relics, and their inscriptions were the subject of endless fascination. Unlike Egyptian hieroglyphics, they could be read, but they were nonetheless approached by many as a kind of northern hieroglyph. ${ }^{10}$

In middle of the seventeenth century, the Danish doctor and collector, Olaus Worm, produced an important treatise on runes that remained the standard work for two centuries. ${ }^{11}$ His text was a major feat of scholarship, but, like other antiquarian projects, it was closely bound up both with state prerogatives and national rivalries. It was made possible in part by a royal decree of 1622 that all bishops and pastors in Denmark should report runic inscriptions in their parishes to Worm. ${ }^{12}$ He identified them as a Gothic legacy, and more specifically as Danish. All comparable material from outside the united kingdom of Denmark-Norway is excluded. Somewhat later, a similar project was to collect and publish the rune stones found in Sweden. They were to be illustrated on a unified scale, thus recognizing the value not only of the inscriptions, but of the stones themselves. This unrealized project was to some degree superseded by a larger effort to document ancient and modern Sweden, published in 1715 as Suecia antiqua et hodierna. For this project, too, provincial priests were asked

9 Jacobowsky C.V., J.G. Sparwenfeld: bidrag till ett biografi (Stockholm: 1932) 79-237.

10 Bach-Nielsen C., "The Runes: Hieroglyphs of the North", in Strasser G.F - Wade M.R. (eds.), Die Domänen des Emblems. Außenliterarische Anwendung der Emblematik (Wiesbaden: 2004) 157-172; Rix R.W., "Runes and Roman: Germanic Literacy and the Significance of Runic Writing", Textual Cultures 6 (2011) 114-144; Håkansson H., "Alchemy of the Ancient Goths. Johannes Bureus' Search for the Lost Wisdom of the Scandinavia", Early Science and Medicine 17 (2012) 500-522.

11 Worm Olaus, Runir seu Danica literatura antiquissima vulgo Gothica dicta (Copenhagen, Melchior Martzan: 1636); idem, Danicorum monumentorum libri sex (Copenhagen, Joachim Moltke: 1643). See also the introduction to runic text by the Swedish antiquarian, Verelius Olaus, Manuductio compendiosa ad runographiam Scandicam antiquam, recte intelligendam (Uppsala, Henricus Curio: 1675). Jørgensen E., Historieforskning og historieskrivning i Danmark indtil aar 180o, 2nd ed. (Copenhagen: 1960) 122-127; Malm M., Minervas äpple. Om diktsyn, tolkning och bildspråk inom nordisk göticism (Stockholm: 1996) 35-42. For Worm more generally, see Schepelern H.D., Museum Wormianum. Dets forudscetninger og tilblivelse (Aarhus: 1971).

12 The reports are collected in Jørgensen F. (ed.), Prcesteindberetninger til Ole Worm, 2 vols. (Copenhagen: 1970-1974). 
to report antiquities in their parishes to the book's producers. ${ }^{13}$ It was never intended that all of the submitted material should be published, but the effect was nonetheless to produce a comprehensive inventory of the kingdom's material heritage.

Architecture was less central to the Gothic debates than other kinds of historical study for some practical reasons. Most obviously, there were fewer old buildings to present than could be found in Rome, Ravenna, or other ancient cities, and none of these bore the evident antiquity and antiquarian value of rune stones or other archaeological finds. Most Swedish towns are not especially old. Stockholm was established in the thirteenth century, and became the permanent seat of government early in the seventeenth century. ${ }^{14}$ Some other towns in the kingdom are older, but few could plausibly be considered antique. Nor were local ancient buildings as physically and aesthetically impressive as the Pantheon, the Baths of Caracalla, or other ancient Roman structures.

Nonetheless, architecture as a source and evidence of a glorious local antiquity played an important role in the Gothicist discourse, and Uppsala stands at the centre of this. A group of impressive burial mounds gives testimony to a much older settlement near the modern city, and were featured prominently in historical publications. Excavations at Old Uppsala, near the modern city, have long yielded finds now dated from the third to the tenth centuries. Although early modern archaeological interpretations often yielded ideologically coloured results that confirmed longstanding assumptions about the Gothic antiquity of the kingdom, the finds nonetheless provided unambiguous physical evidence of an early society in the kingdom that otherwise was largely lacking. These were explained primarily through later texts, such as Adam of Bremen's eleventh-century chronicle of the archbishopric of Hamburg-Bremen, which then included much of Scandinavia. ${ }^{15}$ These mounds are immediately next to the church at Old Uppsala, which is the fulcrum of all of the historical interpretations examined here [Fig. 21.1]. Modern consensus holds that it was built in the twelfth century. ${ }^{16}$ However, already in the sixteenth and seventeenth centuries, the visible seams in the fabric of the structure made it evident that it had endured a long history and had been reshaped numerous times.

13 Vennberg E., “Verkets historia”, in Vennberg E. (ed.), Suecia antiqua et hodierna (Stockholm: 1924; repr. 1983) 5 .

14 Hall T., with a contribution by Rörby M., Stockholm. The Making of a Metropolis (London: 2009).

15 Adam of Bremen, gesta Hammaburgensis ecclesiae pontificum, ed. G. Waitz (Hannover: 1876) 174, trans. as History of the Archbishops of Hamburg-Bremen by F.J. Tschan (New York: 1959), lib. IV, cap. 26-30 (English p. 207-210).

16 Carlsson R., Göthberg H., Dahlbäck G., Lovén C., and Bengtsson H., Uppsala domkyrka II: Domkyrkan i Gamla Uppsala. Nuvarande domkyrkans omgivningar (Uppsala: 2010). 


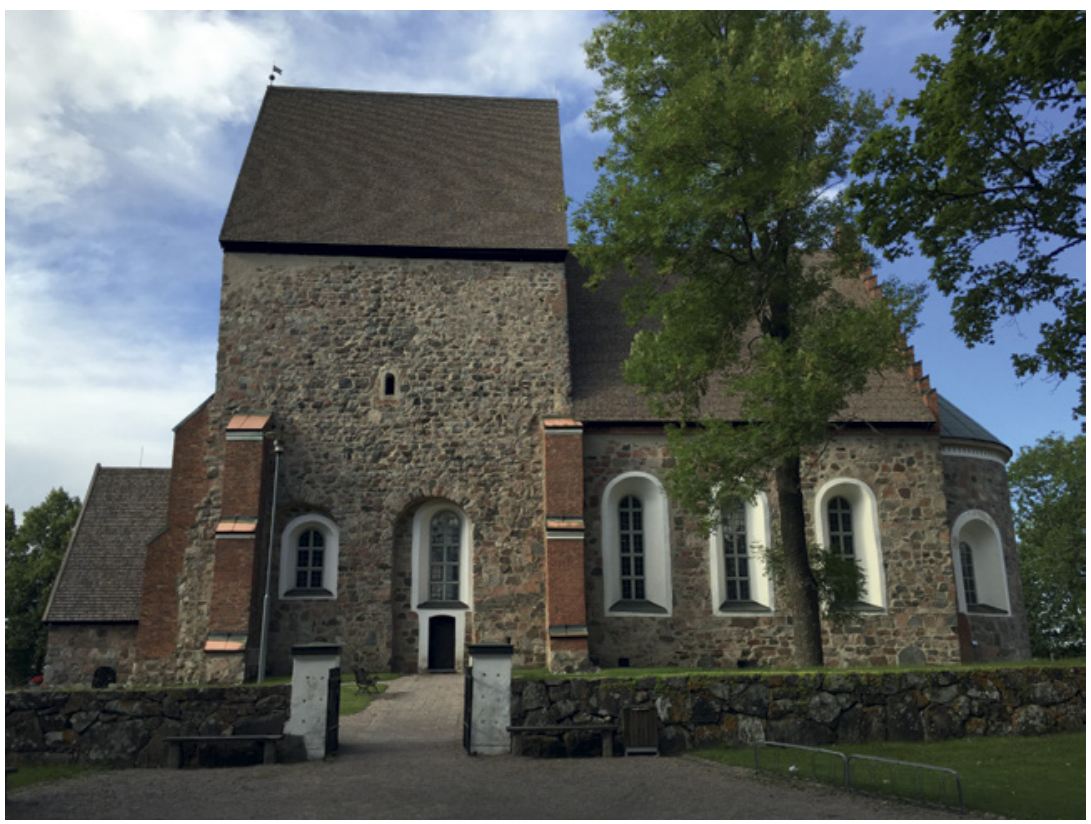

FIGURE 21.1 Church at Old Uppsala (twelfth century with later changes)

IMAGE (C) GABRIEL NEVILLE

This essay introduces a diverse group of published works that integrate the history of architecture - specifically, the temple/church at Old Uppsala - into the Gothicist discourse. The histories of Johannes and Olaus Magnus were fundamental for the tradition. They took a scattered medieval tradition and crafted from it a tradition strong enough to serve as the basis of a state ideology. Johannes Magnus's book in particular became an authoritative text on the subject, and was frequently cited by later historians in the kingdom and elsewhere. Both take up the church, albeit in fairly marginal ways. Suecia antiqua et hodierna (Ancient and Modern Sweden, 1715), a fairly well known topographical survey of the kingdom, was conceived with a similar goal to shape perceptions of the Swedish state. It is a collection of mostly large-format prints of urban views, individual structures, and some other materials that have been popular with collectors for three centuries. Olaus Verelius's edition of the Hervarar saga is known primarily in literary circles, but contains an important architectural component. Finally, Olaus Rudbeck's famous - even notorious Atlantica (1675-1702) presents a wildly revisionist history that places Sweden, and specifically Old Uppsala, at the centre of classical antiquity, employing a wide range of methods, including a detailed historical study of the church on the site. 
Uppsala and its church take an early and central position in the Gothic literature already in the writings of the Magnus brothers. Johannes Magnus's book is structured as a genealogical chronicle, but he works other elements into this. Thus, very early in Book I, he introduces Uppsala. In his telling, Ubbo, the fourth Gothic king, around 246 years after the great flood and in the years before Abraham, established the city of Uppsala, meaning Ubbo's Hall. This soon became the seat both of the kings and of the high priests (Gothorum Pontificibus).${ }^{17}$ Soon thereafter, Magnus returns to Uppsala, departing from the genealogical structure to present the temple and its gods: Thor, Odin, and Frigga. He emphasizes the powers and significance of each, presenting them to his presumed Italian audience in terms of approximate Greco-Roman counterparts. Although he includes a woodcut of the church, he does not describe it or explain its curious content, which would surely have caused wonder among its viewers [Fig. 21.2].

This Johannes left for his brother. Olaus Magnus's book, published a year later, in 1555 , is a loosely organized presentation of the kingdom and its traditions. ${ }^{18}$ It is episodic, but more capable of accommodating architecture and other materials than Johannes's chronicle. To a degree, there is a pendent quality to the two books, and Olaus in particular refers to the work of his brother. In this case, however, the linkage between the two is particularly strong, for both published the same woodcut, which serves as an anchor for their quite

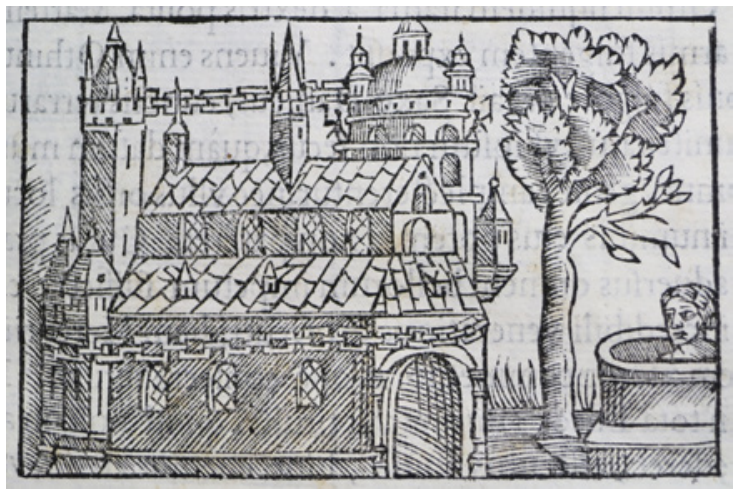

FIGURE 21.2

Ancient Temple at Old

Uppsala. Woodcut illustration from: Johannes Magnus,

De omnibus Gothorum Sueonumque regibus (Rome, Joannes Maria de Viottis:

1554), book I, 29

IMAGE (C) THE HUNTINGTON LIBRARY, SAN MARINO, CALIFORNIA

17 Magnus Johannes, De omnibus Gothorum [...] regibus 29-31.

18 See Johannesson, Renaissance of the Goths; Gillgren P., Vasarenässansen. Konst och identitet i 150o-talets Sverige (Stockholm: 2009) 153-185. 
different comments. (This implies a degree of intentionality, since one must have delivered the woodblock to the other.)

Where Johannes spoke only about the gods worshipped within the temple, Olaus wrote about the structure itself.

Templum igitur [...] nobilissimum a tempore Nini prope fluvium Sala erat, ubi hodie Upsala Sueonum, ac Gothorum Primatialis, et Archiepiscopalis sedes est. Quod adeo magnifico apparatu constructum venerabatur, ut nihil in eius parietibus, laqueariis aut columnis, nisi auro splendidum videretur. Tectum praeterea totum auro fulgebat: a quo aurea catena dependens totum templum ad moenia, domusque fastigia cinxisse memoratur. Quo factum erat, ut templum in ampla planitie situm admirando sui fulgore venerandam religionis maiestatem accessuris ingeneraret. Astabat eius foribus arbor ingens ignoti generis, patulis diffusa ramis, aestate et hyeme iuxta virens [...] Eratque fons huic templo propinquus, qui scaturiit in locum sacrificiorum, de quo mox infra dicetur. Et haec sufficiant exteris nationibus de tali ritu Gothorum nonnihil vanitatis intellexisse.

A temple [...], famous since the time of Ninus, stood by the River Sala, where today the seat of the primate and archbishop of the Swedes and Götar lies. This they so revered, erected as it was in rich magnificence, that you could have seen no part of its inner walls, panelled ceilings, or pillars that did not glitter with gold. The whole roof, moreover, shone with gold, and it is recorded that a golden chain hung down from it to encircle the whole temple including the outer walls and tops of the building. Hence it came about that the temple, situated on a wide plain, with its shining splendour implanted in any persons approaching it an awesome sense of religious grandeur. At its doors stood a huge tree of unknown species, with wide-spreading branches, and leaves green in summer and winter alike [...] Close to the temple there was a spring that gushed out into the sacrificial area, of which I shall soon say more below. Let this be enough to enable foreign nations to understand something of the falsity of such rites among the Goths. ${ }^{19}$

This description accounts for many of the otherwise baffling elements in the woodcut, in particular the two chains wrapped around the structure and the

19 Magnus Olaus, Historia de gentibus septentrionalibus, III, cap. 6 (Latin: p. 104, English: vol. I, p. 156). 
man peeking out from the well at lower right. Although Olaus does not reveal his sources, most of these details are derived from Adam of Bremen's chronicle. ${ }^{20}$

Olaus's description of a golden temple in a natural theater is striking. But he, too, is ultimately concerned with pagan ritual, as the closing sentence of the passage quoted above suggests. He does not develop his description into a full analysis of the structure or use it as historical evidence. Rather, he moves on to discuss rituals among other ancient peoples to show that such heathen practices were universal, and not in any way particular to the Gothic people.

\section{Suecia antiqua et hodierna}

Suecia antiqua is a compilation of 353 printed images presenting the kingdom of Sweden by region. ${ }^{21}$ Erik Dahlbergh, a fortifications engineer, conceived the project and drove it until his death in 1703 . It was begun in 1661 as an individual initiative, but fell increasingly under the sponsorship and control of the state. Thus, in 1664 the crown agreed to finance the work, and it became ever more intertwined with state prerogatives and Gothic ideology. ${ }^{22}$ Already in 1661 the court historiographer, Johannes Loccenius, was commissioned to provide an accompanying text. He left a substantial fragment at his death in 1677 . After an extended delay, responsibility for the text fell to the State Board of Antiquities, a government body dedicated to finding, preserving, and publishing materials related to the kingdom's history. ${ }^{23}$ One of the fundamental goals of the Board of Antiquities was the promotion of a Gothic heritage. Several authors prepared

20 Adam of Bremen, Gesta IV, cap. 26-30 (English p. 207-210).

21 Dahlbergh Erik, Suecia antiqua et hodierna (Stockholm, n.p.: 1715). See Vennberg, "Verkets historia" 1-122; Bring S., "Sueciaverket och dess Text", Lychnos (1937) 1-67; Magnusson B., Att illustrera fäderneslandet: en studie i Erik Dahlberghs verksamhet som tecknare (Uppsala: 1986); idem, 'Sweden Illustrated: Erik Dahlbergh's 'Suecia Antiqua et Hodierna' as a Manifestation of Imperial Ambition", in Ellenius A. (ed.), Baroque Dreams: Art and Vision in Sweden in the Era of Greatness (Uppsala: 2003) 32-59; Neville K., "Suecia antiqua et hodierna. The Life of a Topographical Viewbook in the Eighteenth Century", Print Quarterly 30 (2013) 395-408; Magnusson B. and Nordin J., Drömmen om stormakten. Erik Dahlberghs Sverige (Stockholm: 2015). High-quality scans of the plates, as well as surviving proofs and drawings, can now be found online at suecia.kb.se.

22 For Suecia antiqua and Gothic ideology, see Frick J., "Erik Dahlbergh och den götiska utopin i Suecia antiqua et hodierna", Karolinska förbundets årsbok (2009) 192-242; Neville K., "The Land of the Goths and Vandals. The Visual Presentation of Gothicism at the Swedish Court, 1550-1700", Renaissance Studies 27 (2013) 395-408.

23 For the Board of Antiquities, see Schück H., Kgl. Vitterhets historie och antikvitets akademien: dess förhistoria och historia, 8 vols. (Stockholm: 1932-1944); Norris M., A Pilgrimage 
drafts, all of which incorporated the Gothic argument in some form. None was completed, however, and the volume was eventually published without a text. ${ }^{24}$

Suecia antiqua et hodierna is an historical topography with a heavy emphasis on architectural and city views. In its final form, it lacks the balance of past and present implied in the title. The modern component of the work dominates to a degree that could not have been anticipated. In 1661, there were relatively few contemporary structures impressive enough to merit inclusion. Work on Suecia antiqua coincided with a building boom in the kingdom, however, and many new palaces and churches were built, providing new material for the book. A number of noble patrons wrote to Dahlbergh, often rather imperiously, to ensure that their new residences were presented prominently in the topography, frequently in suites of prints. ${ }^{25}$

The antique component of Suecia antiqua is thus substantially more marginal than was likely intended. Nonetheless, we find a number of images of different kinds of antiquarian materials: a battered statue presented as an idol of Thor; rune stones; ancient ritual sites; the runic, Gothic, and Latin alphabets in a comparative chart; medieval coins; and so on [Fig. 21.3]. ${ }^{26}$ Gothic and Norse narratives were conflated, so that Thor and other Norse gods were perceived as part of the Gothic heritage, which was in turn confirmed through objects such as pagan votive figures.

Architecture is the primary means through which the achievements of modern Sweden are demonstrated, but it is marginal in the presentation of the kingdom's antiquity. Although a number of medieval churches are included, these are often presented either in the context of town views or of the monuments housed within them, rather than as monuments in themselves. Even when they are the primary subject of the print, the inscriptions give little indication that the older churches carried any substantial historical significance.

to the Past. Johannes Bureus and the Rise of Swedish Antiquarian Scholarship, 1600-1650 (Lund: 2016).

24 The various drafts of the text for Suecia antiqua are preserved in the Royal Library in Stockholm. See Vennberg, "Verkets historia" 1-144; Bring, "Sueciaverket och dess text" 1-67; Magnusson and Nordin, Drömmen om stormakten 137-147, 195-223.

25 For instance, Dowager Queen Hedwig Eleonora wrote to Dahlbergh in 1668 about the inclusion of her 'newly begun house', Drottningholm Palace. See Vennberg, "Verkets historia" $28-29$.

26 The runic alphabet is presented as an older version of the Gothic alphabet used in the Bible translation of Wulfila, kept from 1669 in Uppsala University Library, and published in two separate editions in 1665 (by Franciscus Junius) and 1671 (by Georg Stiernhielm). For the manuscript's importance in the seventeenth century, see McKeown S., "Recovering the Codex Argenteus: Magnus Gabriel de la Gardie, David Klöcker Ehrenstrahl and Wulfila's Gothic Bible", Lychnos (2005) 9-28. 


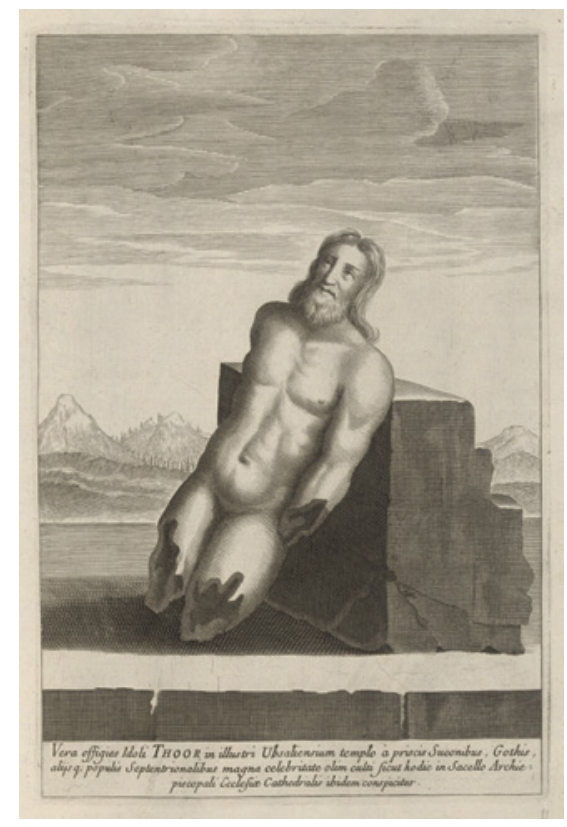

FIGURE 21.3

Thor. Etching from Erik Dahlbergh, Suecia antiqua et hodierna (Stockholm, n.p.: 1715) IMAGE (C) THE ROYAL LIBRARY, STOCKHOLM

With few exceptions, medieval churches seem not to have been of special interest to the producers of the book.

The exception to this is the church at Old Uppsala. Although it is now generally regarded as a twelfth-century building structurally comparable to scores of others scattered around the region, it was then widely regarded as an ancient structure and central to the early history of the kingdom. Accordingly, it plays a unique and central role in Suecia antiqua [Fig. 21.4]. The print brings together a view of the Christian church as it could be seen in the seventeenth centuryemphasizing its masonry seams - with an imaginative view of it in antiquity, thus bringing together in a coherent continuity the ancient and the modern.

Adam of Bremen describes the site in this way:

Illa gens templum habet, quod Ubsola dicitur, non longe positum ab Sictona civitate. [...] In hoc templo, quod totum ex auro paratum est, statuas trium deorum veneratur populus, ita ut potentissimus eorum Thor in medio solium habeat triclinio; hinc et inde locum possident Wodan et Fricco.

That folk has a very famous temple called Uppsala, situated not far from the city of Sigtuna. [...] In this temple, entirely decked out in gold, the people worship the statues of three gods in such wise that the mightiest 


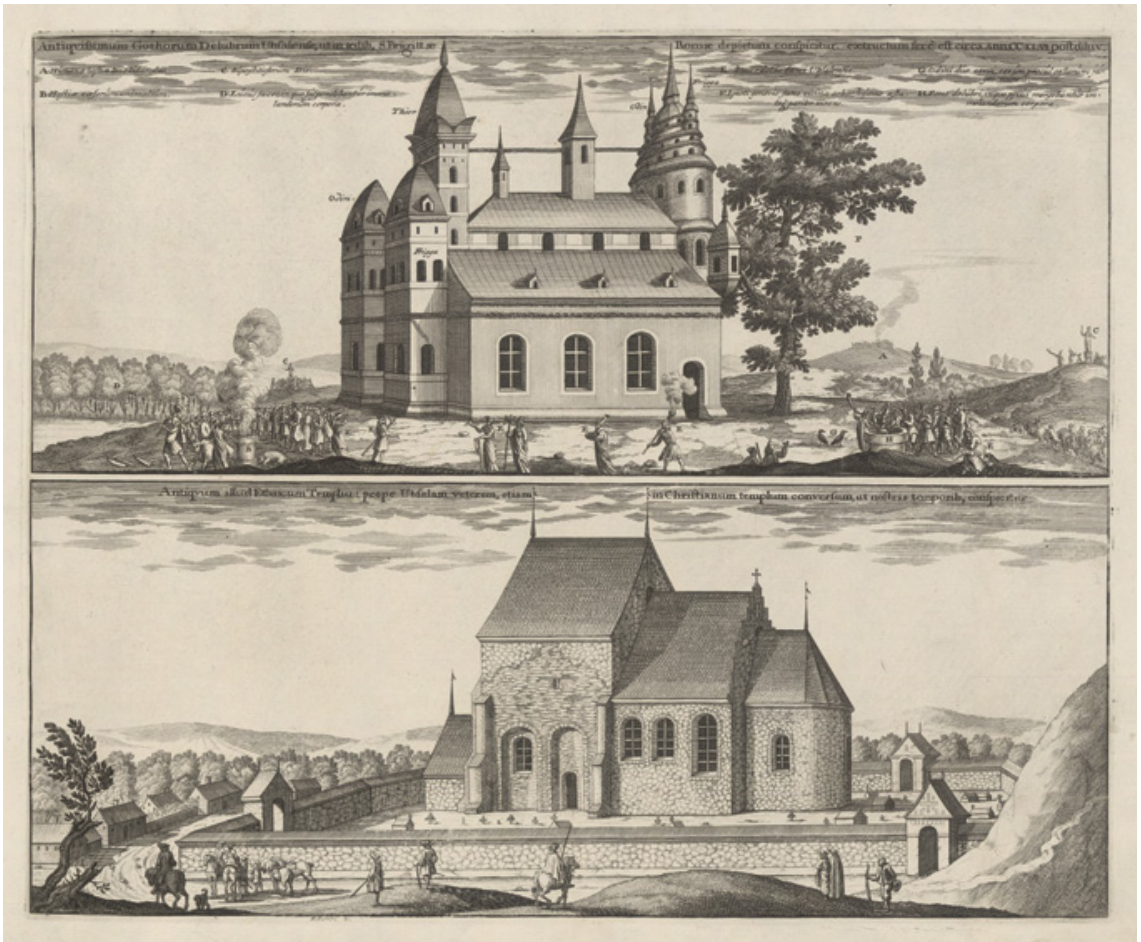

FIGURE 21.4 Ancient temple and church at Old Uppsala. Etching from Erik Dahlbergh, Suecia antiqua et hodierna (Stockholm, n.p.: 1715) IMAGE (C) THE ROYAL LIBRARY, STOCKHOLM

of them, Thor, occupies a seat in the middle of the chamber; Wotan [Odin] and Frikko [Frigga] have places on either side.

Early textual additions, which were passed on as authoritative, state:

Prope illud templum est arbor maxima late ramos extendens, semper viridis in hieme et aestate; cuius illa generis sit, nemo scit. Ibi etiam est fons, ubi sacrificia paganorum solent exerceri et homo vivus immergi [...] Catena aurea templum illud circumdat pendens supra domus fastigia, lateque rutilans advenientibus, eo quod ipsum delubrum in planitie situm montes in circuitu habeat positos ad instar theatri.

Near this temple stands a very large tree with wide-spreading branches, always green winter and summer. What kind it is nobody knows. There is also a spring at which the pagans are accustomed to make their sacrifices, 
and into it to plunge a live man [...] A golden chain goes round the temple. It hangs over the gable of the building and sends its glitter far off to those who approach, because the shrine stands on level ground with mountains all about it like a theater. ${ }^{27}$

Adam's text was thus the source for many of the elements in the image in Suecia antiqua, as it had been for the woodcut in the Magnus brothers' books. The group of three towers, identified by inscriptions with the Norse gods Odin (represented indirectly by the two ravens beneath the tree), Thor, and Frigga, provides a way to show through the structure of the building the gods worshipped within. In the foreground we find a group of pagan priests wearing long, flowing gowns and bearing horns. In the middle ground to the right and the left we see idol worship, and in the foreground and extreme distance scenes of human and animal sacrifice, detailed elsewhere in Adam's description. The image of a man dropped in a well, seen at lower right, the tree near the temple, and the great golden chain encircling the building, visible both above the firstfloor windows and stretching between the two highest towers are also based on Adam's description. However, they are derived more directly from the print published by the Magnus brothers.

Adam of Bremen's description is both precise and laconic. Some aspects of it, such as the statement that it was 'entirely made of gold', and the enthusiastic elaboration of this by Olaus Magnus, were not easily shown in a black-andwhite print. In this context, the golden chain becomes something of a standin for the overall richness of the building. Likewise, the description of Thor as the main dedicatory god likely explains the description of the fragmentary figure - presumably actually a mutilated medieval figure of a saint - as Thor, despite the apparent lack of any justification for this identification [Fig. 21.3]. The inscription on the print states that it came from the temple of Uppsala, and could then be seen in the cathedral in Uppsala.

The reconstruction of the temple at Old Uppsala stands apart from virtually all other architectural views in Suecia antiqua in its extensive and detailed historical inscriptions. ${ }^{28}$ These identify each of the elements noted above, with the exception of the golden chain. A more prominent inscription describes the structure as the Gothic temple in Uppsala. When we take into account the towers dedicated to Norse gods, the conflation of the Gothic and the Norse found throughout the literature is brought to the fore. The note that the structure

27 Adam of Bremen, Gesta IV, cap. 26 and schol. 134-135 (Latin p. 174, English p. 207).

28 Only the print of the medieval Linköping Cathedral, which includes a short history of the building, is comparable. 
was built 'about the year 246 after the flood' gives it a precise historical placement based on the authority of Johannes Magnus. Perhaps more importantly, this brings both the Gothic and the Norse historical visions into a Biblical framework.

The presentation of the church at Old Uppsala occupies an important place in Suecia antiqua illustrating the history of a crucial ritual site. However, it exists more or less in isolation in the work. Other prints refer to Gothic remains of various kinds, but these more often present individual objects or sites associated with Gothic battles or worship. Even without the accompanying text, the reconstruction and the inscriptions present a kind of architectural development illustrating a cultural continuity between the ancient and modern site, and the ancient and modern people who occupy it. It comes closer than almost any other plate to bringing together the ancient and the modern promised in the title of the work.

The presentation of Old Uppsala in Suecia antiqua was entirely in keeping with the Gothicist discourse, and complemented by other plates showing related materials, such as the earthen mounds near the church and other ancient objects. However, the church is nearly lost among the scores of plates of more contemporary palaces and churches, and only a knowledgeable and perceptive viewer could place it within the larger historical narratives informing it. This was largely accidental, however. In contrast to the intentions of the producers, the book is essentially non-textual. The only explanatory texts are in the form of inscriptions. The various fragmentary manuscripts make clear that the Gothic theme would have been fully developed in the textual component of the book.

The essentially visual presentation in Suecia antiqua finds a counterpoint in the presentation of the church by Olaus Verelius (1618-1682). This comes in a literary context, in his publication of the Icelandic epic Hervarar Saga. Like other editions of early texts published by historians in Stockholm and Uppsala, this editio princeps is heavily annotated, not least in order to emphasize its role as evidence of the Gothic past. ${ }^{29}$ Verelius was part of the Uppsala circle of antiquarians and a member of the State Board of Antiquities, which embraced as part of its mission the identification and publication of texts relevant to

29 Verelius Olaus, Hervarar saga på Gammal Götska med Olai Vereli uttolkning och notis (Uppsala, Henricus Curio: 1672). 
the history of the kingdom. It is in his commentary that we find an historical analysis of the church at Old Uppsala.

Verelius's notes on the church are also informed by a more local dispute with another Uppsala academic, Johannes Schefferus, on the site and identification of the ancient temple described by Adam of Bremen. Schefferus argued that the building was lost long ago, and had stood on the site of the cathedral in (modern) Uppsala. ${ }^{30}$ Verelius identified it with the church at Old Uppsala, which informs his exposition of the historical significance of the site. This builds in part on Adam of Bremen's description of the temple with altars dedicated to Thor, Odin, and Frigga, juxtaposed with an extended description by Ericus Olai, a fifteenth-century Swedish chronicler, placing it next to a group of earthen mounds, which indeed stand next to the church in Old Uppsala. ${ }^{31}$

Quite typically of sixteenth- and seventeenth-century historians, this begins with an etymological explanation of the name and a topographical description of the region and its history. ${ }^{32}$ This culminates in a presentation of the church itself, illustrated - uniquely in the book - with two large woodcuts [Figs. 21.5, 21.6]. ${ }^{33}$ The first shows the church in plan and view in its seventeenth-century form, with obviously disjunctive elements. The captions emphasize this, and divide the church's construction history into two distinct periods: the ancient building (aedificium vetus Ethnicum), comprising the older square stone structure, and the church of the Christian population (templum Christianorum), which Verelius identifies as the choir and the apse added on to the earlier structure. It further indicates adjustments made in the context of the addition of the Christian structure (the expanded opening on the wall facing the expansion). The scale under the plan suggests that Verelius has measured the structure, and thus carried out a substantial on-site investigation of the building. This brief architectural history is summarized in the main text as well. ${ }^{34}$

The historical survey outlined in Verelius's first woodcut enables the reconstruction of the original form of the structure presented in the second. Here

30 Schefferus Johannes, Upsalia, cujus occasione plurima in religione, sacris, festis, [...] explicantur (Uppsala, Henricus Curio: 1666). See generally Ellenius A., "Johannes Schefferus and Swedish Antiquity", Journal of the Warburg and Courtauld Institutes 20 (1957) 59-74.

Verelius, Hervarar saga, 62-66. This is presented and contextualized by Jackson Williams K., The Antiquary:John Aubrey's Historical Scholarship (Oxford: 2016) 37-39. Cf. Olai Ericus, Chronica regni Gothorum, 2 vols., ed. E. Heuman and J. Öberg (Stockholm: 1993-1995).

32 For the significance of etymologies in early modern antiquarianism, see Vine A., In Defiance of Time. Antiquarian Writing in Early Modern England (Oxford: 2010) 51-79.

33 There are four other woodcuts in the book. Three show rune stones, and one shows a group of runic characters.

Verelius, Hervarar saga 64. 


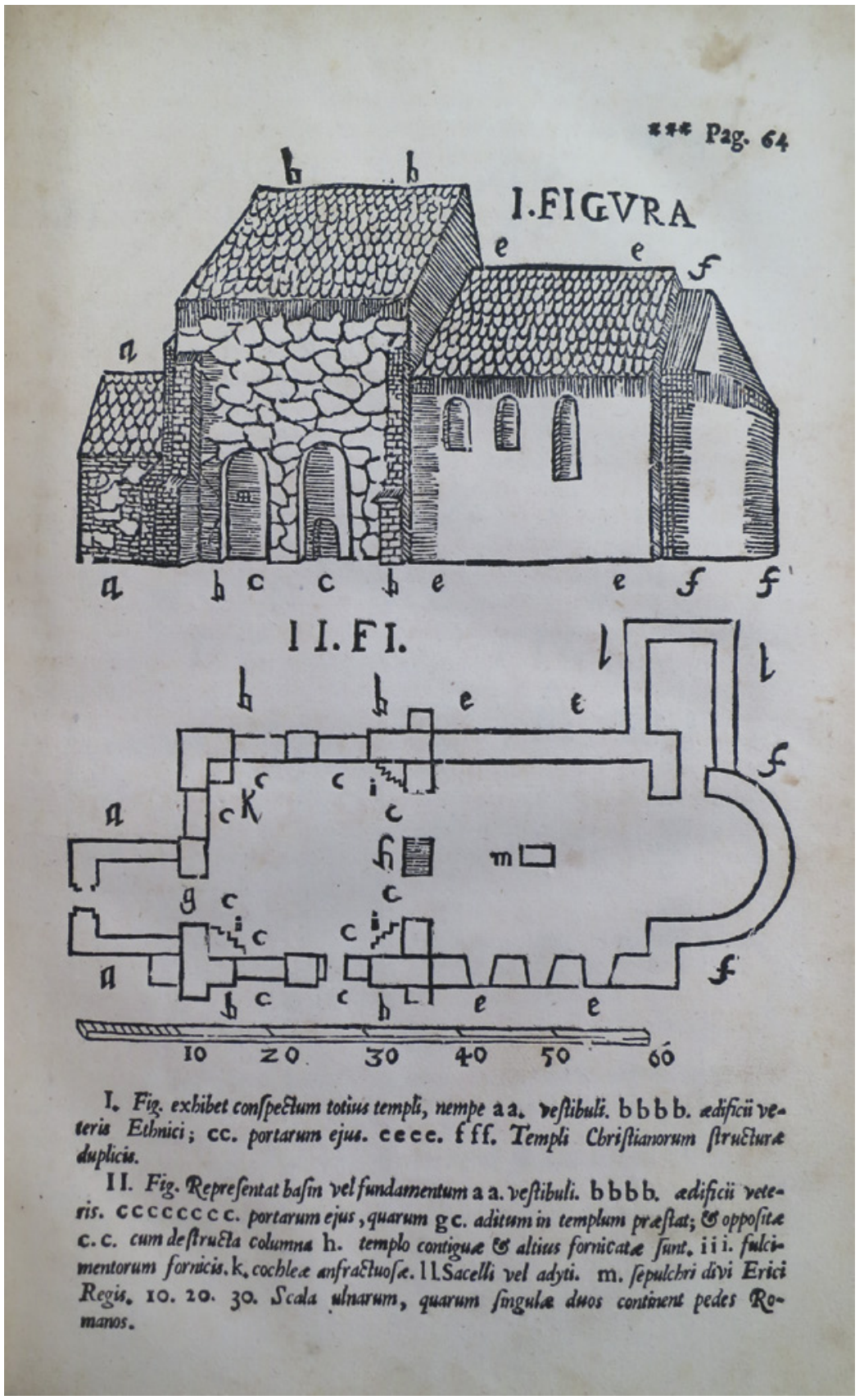

FIGURE 21.5 Seventeenth-century church at Old Uppsala. Woodcut from Olaus Verelius, Hervarar saga på Gammal Götska med Olai Vereli uttolkning och notis (Uppsala, Henricus Curio: 1672)

IMAGE (C) THE HUNTINGTON LIBRARY, SAN MARINO, CALIFORNIA 


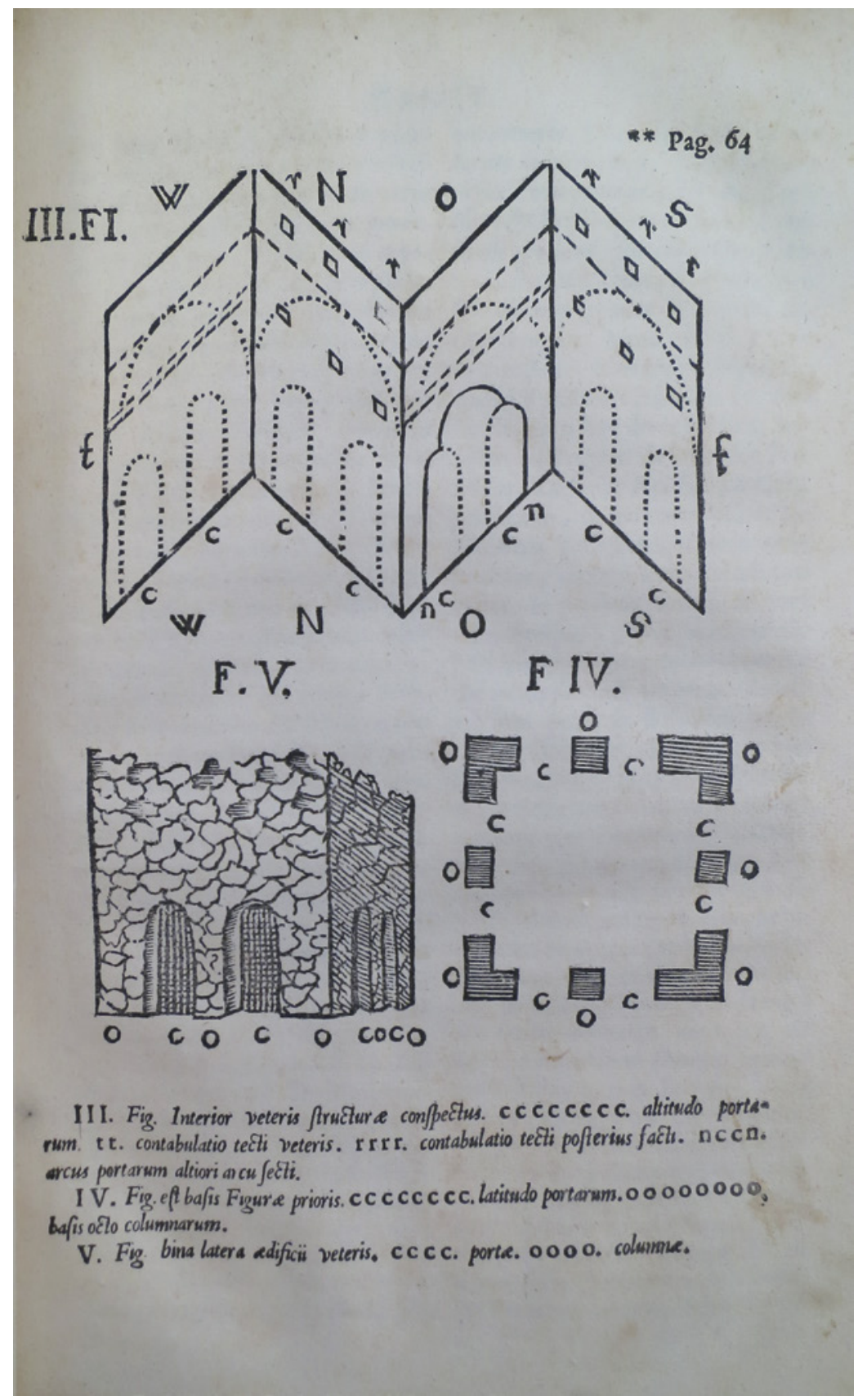

FIGURE 21.6 Ancient temple at Old Uppsala. Woodcut from Olaus Verelius, Hervarar saga på Gammal Götska med Olai Vereli uttolkning och notis (Uppsala, Henricus Curio: 1672)

IMAGE (C) THE HUNTINGTON LIBRARY, SAN MARINO, CALIFORNIA 
we encounter the structure shorn of all later accretions. Once again we find a plan and a view, now accompanied by an innovative, early worm's eye view. Unlike the other views, this does not indicate the mass of the building, and the portals and other structural features are only summarily indicated. The walls have been unfolded like a screen to show all four elevations in their original configuration, all at ninety-degree angles to one another. This allows him to show the original vaulting and other elements that otherwise are generally lost in these reconstructions.

Verelius's discussion of the temple is largely oriented to his concern to link the saga to a locally specific version of the Gothic narrative. Nonetheless, he shows a comparative eye in a passing - but fairly specific - Roman comparison, noting that the height, 'broad columns' (latis columnis; i.e., piers) and rounded arches all recall the temple of Janus in Rome. ${ }^{35}$ Although the comparison is not developed or exploited further, it introduces a concrete point of reference within the canonical classical world, and places it within a larger architectural tradition than does Suecia antiqua.

Verelius does not develop all of his observations, and they are subordinated to the text that is the focus of the book. Nonetheless, they were enormously important, for his discussion and his methods contain many of the seeds for the crucial discussion of the church in the massive and conceptually extraordinary Atlantica of the Uppsala professor Olaus Rudbeck (1630-1702).

Rudbeck was the most remarkable polymath in Sweden in the seventeenth century. ${ }^{36}$ In 1652 , he presented his discoveries on the human lymph system to Queen Christina and her court. This led to a stipend to spend the following academic year in Leiden, where he pursued anatomical studies. The year in Leiden may also have awoken a deep interest in botany. He later established a botanical garden for the university in Uppsala, and undertook an extensive study of Nordic flora. He published only the first part of this before losing his materials in the Uppsala city fire of 1702 , the year of his death. ${ }^{37}$

Certainly, the academic studies he pursued in Leiden were of great interest, but he was almost equally impressed by the architecture that he found in the

35 Verelius, Hervarar saga 64.

36 Eriksson G., Rudbeck 1630-1702: liv, lärdom, dröm i barockens Sverige (Stockholm: 2002).

37 Rudbeck Olaus, Campus elysius (Uppsala, n.p.: 1701-1702). 
Netherlands. These various interests came together in a group of structures that Rudbeck designed for the university. He built an anatomical theatre atop the main university building in Uppsala in 1662-63. This was derived in large part from the anatomical theatre in Leiden, which builds to some extent on Roman theatre design. The octagonal form with large clerestory windows may be derived from the Marekerk in the same city, built by Arent van 's-Gravesande in 1639-1649. ${ }^{38}$ He also designed a suite of buildings for the new university gardens. ${ }^{39}$ More generally, he established and oversaw an architectural program within the university that brought together theoretical and practical training, with all instruction in the vernacular. In the course of four decades, it produced students who pursued careers in various technical building careers. This recalls the Duytsche Mathematique program established in Leiden by Simon Stevin at the turn of the seventeenth century. Rudbeck pointed rather obliquely to Stevin's initiative when he cited Frans van Schooten the Younger, who held a post in the Duytsche Mathematique at midcentury, as his immediate model in the endeavour. ${ }^{40}$

Rudbeck's other driving interest was ancient history, studied through a combination of a text-based, philological method and an antiquarian approach, which also took account of architecture. This is on full display in his Atlantica, published in three volumes in $1675^{-1702 .{ }^{41}}$ Rudbeck naturally explains that Sweden was the homeland of the Goths, following the official line of Swedish history writing for over a century. Rudbeck pushes this logic further than any other writer, however. He argues that the kingdom was also identical with the island of the Hyperboreans, Scythia, Atlantis, and many other places described in ancient texts.

These identifications of Sweden with many ancient lands allowed Rudbeck to trace nearly everything of historical significance to earlier roots in the kingdom. Thus, he presents a series of philological mutations as the basis for an argument that the Egyptian and Greco-Roman gods are derived from earlier

38 Lindahl G., Universitetsmiljö: byggnader och konstverk vid Uppsala universitet (Uppsala: 1957) 50-64.

39 Eriksson, Rudbeck 198-207.

40 Dahl P., Svensk ingenjörskonst under stormaktstiden. Olof Rudbecks tekniska undervisning och praktiska verksamhet (Uppsala: 1995).

41 Rudbeck Olaus, Atland eller Manheim (Uppsala, Henricus Curio: 1675-1702; repr. ed. Axel Nelson, Uppsala: 1937-1939). All citations are from the Nelson edition. For commentary on the text, see Eriksson G., The Atlantic Vision. Olaus Rudbeck and Baroque Science (Canton, Mass.: 1994); idem, Rudbeck, 257-496. For the legacy of Plato's legend, see Vidal-Naquet P., The Atlantis Story. A Short History of Plato's Myth (Exeter: 2007). 
ones in his homeland. ${ }^{42}$ Likewise, he argues that the Greek alphabet was derived from the runic one. ${ }^{43}$

The church at Old Uppsala appears several times in Atlantica. Like Verelius, he identified it as the temple described by Adam of Bremen, drawing on both textual and material evidence. He pushes further, however, and also identifies it as the main Temple of Poseidon on Atlantis, described by Plato very briefly in the Timaeus, and at greater length in the fragmentary Critias. ${ }^{44}$ This architectural identification serves as the basis for two larger arguments. The first is a broad claim, central to the thesis of the book, that Plato's Atlantis was never lost, but is properly identified as Sweden. This view is supported by complementary arguments based on many other kinds of historical evidence. The second argument is that the structure in Old Uppsala represents a starting point for the development of classical architecture, which spread and developed from Sweden to ancient Egypt, Greece, and Rome.

Rudbeck's justification for this is long and complex, and weaves together many different kinds of historical argument. One strand of this develops an essentially antiquarian argument, based on study of the fabric of the church in Old Uppsala. The heart of this is his reconstruction of the original form of the temple. Like Verelius, he derives from the standing structure an earlier form that was square in plan, with two arched openings on each side [Fig. 21.7]. Each side had a high pitched roof, which was subsequently altered and the masonry extended upward to support the current form. Rudbeck shows the adjustments and resulting masonry seams in a second woodcut. These are also visible in the plate from Suecia antiqua.

Rudbeck's reconstructed original form serves as the basis for an extensive analysis that places the building within a Greco-Roman history of architecture. This is based in part on a rather free reading of Vitruvius's descriptions of temple types, and in part on descriptive comparisons. ${ }^{45} \mathrm{~A}$ temple may be partially enclosed, we are told, or an open hall. Using an associative philological argument common throughout Atlantica, in which similarities in words within or among languages become evidence of historical ties, Rudbeck points out that in Swedish, an 'open hall' is an 'öppen sal'. This is a near-homophone

\footnotetext{
42 Rudbeck, Atland eller Manheim, vol. II, 449-595.

43 Rudbeck, Atland eller Manheim, vol. I, 524-542.

44 Plato, Timaeus and Critias, ed. A.E. Taylor (London: 2012), 120; Adam of Bremen, History of the Archbishops of Hamburg-Bremen 207; Rudbeck, Atland eller Manheim, vol. I, 156-165.

45 Rudbeck, Atland eller Manheim, vol. I, 157-161. Rudbeck cites Vitruvius I,2 and IV,7, neither of which supports his claims. Temple types are discussed in Vitruvius III and IV, though without clear justification for Rudbeck's arguments.
} 


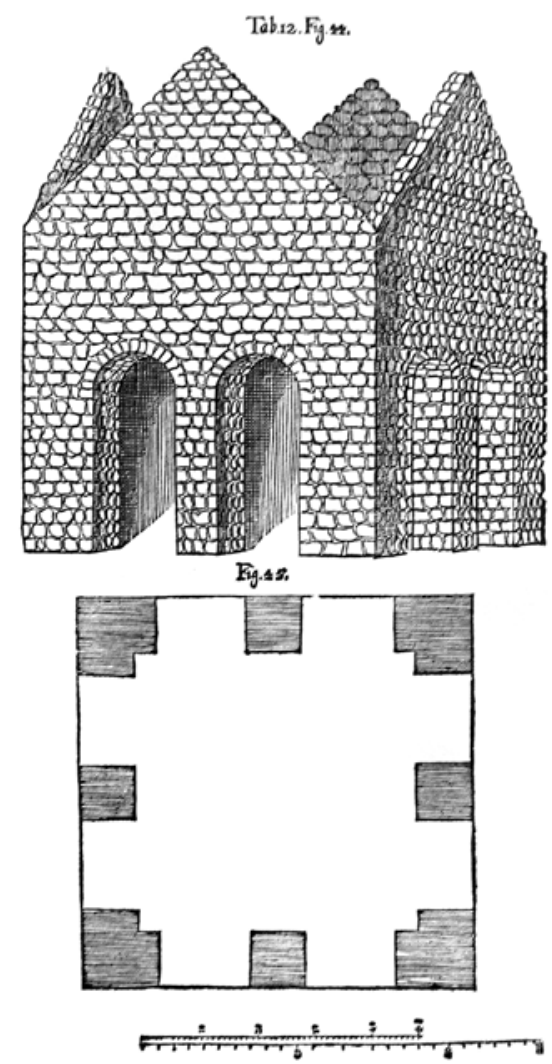

FIGURE 21.7

Olaus Rudbeck, Ancient temple at Old Uppsala. Woodcut from: Olaus Rudbeck, Atland eller Manheim (Uppsala, Henricus Curio: 1675-1702) IMAGE (C) REPR. ED. AXEL NELSON (UPPSALA: 1937-1939), IMAGE VOLUME, PLATE 12

of 'Uppsala', and he links the two. ${ }^{46}$ This forms the basis for an argument that the ancient temple in Old Uppsala was originally open, and was walled up in later changes. ${ }^{47}$

Verelius had casually mentioned the Temple of Janus as a point of comparison, without further comment and seemingly without drawing any great significance from it. Rudbeck refers to that temple among others to place the church at Old Uppsala within standard typologies of ancient architecture; it represents four-sided structures with interior chambers. Among the open, round structures he includes temples of Mars, Vesta, and Juno. Among the open, four-sided types he cites the temple of Apollo by the Circus Maximus and that of Jupiter Ammon in Verona. ${ }^{48} \mathrm{~A}$ full list of sources accompanies all

46 Rudbeck, Atland eller Manheim, vol. I, 155, 157 .

47 Rudbeck, Atland eller Manheim, vol. I, 157-165.

48 An arch of Jupiter Ammon in Verona is well known, most especially through Andrea Palladio's drawings of it. However, the early modern antiquarian literature mentions a 
of these references. Many of these are early modern antiquarian publications of various kinds, particularly those containing architectural reconstructions or the base evidence for these, such as coins and medals. Like many contemporary antiquarians, he reproduces ancient coins with images of architecture on the reverse as evidence [Fig. 21.8]. Many of the coins he cites are in fact copied from this antiquarian literature - most often earlier literature from the sixteenth century - indicating that his approach is to some degree an elaboration of it. ${ }^{49}$

Although Rudbeck draws on the fabric of the building and many of the same texts used by other writers, he reconstructs the original building in a rather different form than did the producers of Suecia antiqua, for instance. The essentially comparative antiquarian approach outlined above established the building within the Greco-Roman tradition to Rudbeck's satisfaction. However, to demonstrate that it was in fact the Temple of Poseidon on Atlantis, and thus very ancient even in Plato's time, he needed a more precise argument. One aspect of this is an essentially topographical argument, in which he surveys the landscape around Uppsala and matches it to the details given in the Critias dialog..$^{50}$ To some degree, this method also worked for the building itself. He accounts for the dimensions given by Plato, and introduces various sources to show that the materials and decorative richness matched. Thus, for instance, he cites Plato's description of the temple on Atlantis:

Salens yttre delar eller wäggiar bedrogo de öfwer med Silfwer, förutan de öfwerst kiediorna (listerna) hwilka woro med gull bedragne. In uti war Taket beprydt med Elfwenbeen, Gull, Silfwer, och Koppar utarbetat, men wäggiarna, pelarna och golfwet war alt med Koppar öfwerdragit. ${ }^{51}$

The room's [salens] outer parts or walls were covered with silver, except for the uppermost chains (moldings), which were gilded. Inside the

temple of Jupiter Ammon in the city as well. See e.g., Biancolini Giovanni Battista, Notizie storiche delle chiese di Verona vol. I (Verona, Alessandro Scolari: 1749) 104.

49 Rudbeck cites many authors, but often in a fragmentary form and without indicating the title or the place or year of publication, making it difficult to verify his use of sources. Nonetheless, in this context he frequently cites the publications of Guillaume du Choul (1496-156o), Hubert Goltzius (1526-1583), and Onofrio Panvino (1529-1568), among others.

5o See Neville K., "Antiquarianism without Antiques. Topographical Evidence and the Formation of the Past", in Roling B. (ed.), Boreas Arising from the East. Antiquarianism and Orientalism in Art and Scholarship around the Baltic Sea (Berlin: In press).

51 Rudbeck, Atland eller Manheim vol. I, 163-164. 

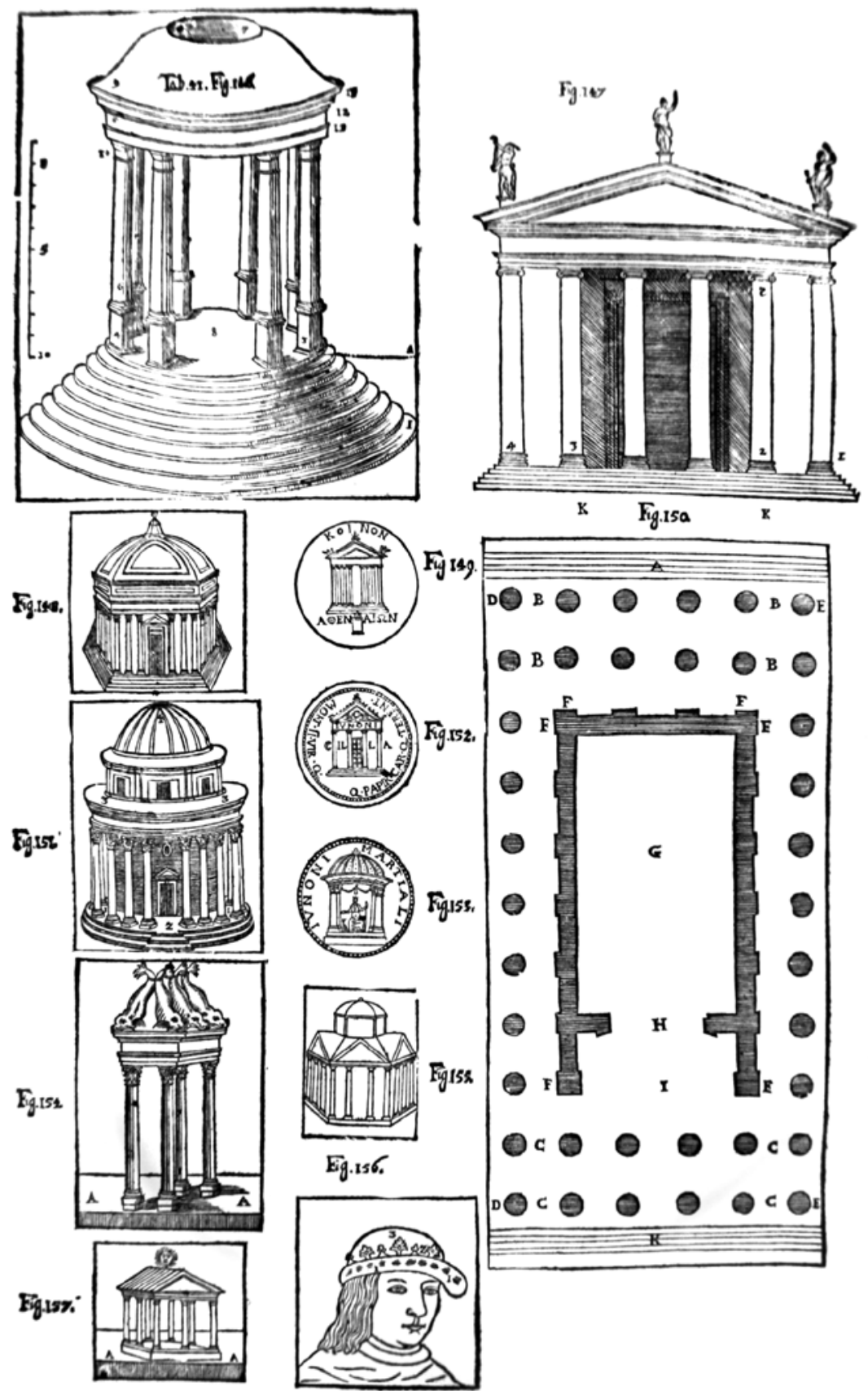

FIGURE 21.8 Olaus Rudbeck. Ancient temples. Woodcut from: Olaus Rudbeck, Atland eller Manheim (Uppsala, Henricus Curio: 1675-1702)

IMAGE (C) REPR. ED. AXEL NELSON (UPPSALA: 1937-1939), IMAGE VOLUME, PLATE 41 
ceiling was ornamented with worked ivory, gold, silver and copper, but the walls, pillars and floor were all covered in copper.

Rudbeck juxtaposes this with the description in the Edda of a temple built of silver and Adam of Bremen's description of the church of gold, and supplements these authorities with the later arguments of Johannes Magnus and Olaus Worm. The disparities between gold and silver, among many other problems that were bound to arise, are neither concealed nor explained. However, Rudbeck labours somewhat more subtly to produce other evidence unifying these descriptions. Thus, Plato's description of the golden external elements - usually translated as 'pediments' or 'pinnacles' - are given by Rudbeck as 'chains' (kiediorna). This corresponds well with Adam of Bremen's description of an enormous gold chain encircling the structure, but is difficult to reconcile with a classical temple. Evidently recognizing that this was likely to confuse the reader, he added 'moldings' or 'stringcourses' (listerna) in parentheses. Elsewhere, he used the same term variously to refer to architraves, friezes, and cornices, all standard components of classical architecture. ${ }^{52}$

The obviously rustic quality of the church did not pose a problem in Rudbeck's analysis. Nor did the lack of columns or other elements typical of ancient building. Indeed, he does not present the standing church as a particularly monumental structure. Rather, he embraces the unrefined quality of the materials and workmanship, which becomes evidence of the building's tremendous antiquity: it was so ancient that it represented a still-imperfect stage of architecture that was later refined and developed by the Greeks and Romans.

Plato säger och att denne ypna Saal war något plumpt bygder effter wår art: hwilket intet skal falla någon underligit, emedan uthi den första tiiden straxt effter Floden, man då intet wiste här eller mång annorstädes af att bränna Tegel eller hugga Steen, utan Gråsteen togs sådan han fans, och antingen utan Leer eller med Leer och Sand bands tilsammans. Hwar igenom ey möjeligit war att några zirater med Gråstenar giöra, utan hwad sedermera hafwer kunnat skedt med fodring utan på aff Timber och Bräden, och der utan på Gull och Silfwer, hwilket lät sig wäl giöra. Sådan des enfaldige skapnadt seer man uti den 44 Fig.: 12 Tafl. [Fig. 21.7] efter sådan grofheet som Plato dhen beskrifwer. Hwilket är och ett stort skiäl till des ålder. Ty alle Lärde erkienna sådana wärck af ju större ålder wara, ju enfaldigare och af gröfre ämbne dhe äro bygde; sannerlig hade dhen 
tiid Bygningskonsten warit i dhet tillståndh som hon war i Salomons, eller de Grekers och Romarers tiid, wisserligen hade dhe så wäl beflitat sig att få en Byggmästare, som efter de fremmandes art hade bygdt dem ett Tempel $\left[\ldots . .{ }^{53}\right.$

Plato says also that that open hall was rather coarsely built in our manner. No one should find this curious, for in the earliest time after the flood, one did not know here or in many other places how to bake bricks or cut stone. Rather, granite was taken where it was found, and joined either without clay or with clay and sand. Through this method, it was impossible to make ornament in granite. But it could then have happened that the exterior was trimmed with timber and boards and covered with gold and silver, which was done. Such a simple creation is seen in fig. 44 of the 12th plate [Fig. 21.7], with such coarseness as Plato describes. Which is also great evidence of its age. For all learned people recognize works to be of greater age, the simpler and of coarser materials they are built. Indeed, if the art of building had been at the state that it was in the time of Solomon, or in the time of the Greeks and Romans, certainly they would have exerted themselves to get an architect who would have built them a temple in the manner of the foreigners [...].

This approach fits Plato's description of the temple on Atlantis as having a 'strange barbaric appearance', but it also supports the thesis that Greco-Roman antiquity was derived from Gothic culture. Accordingly, we should also read these visual comparisons in an order that we are unaccustomed to. Although the Greco-Roman types justify and support Rudbeck's argument, as an historical development, we are to understand them to develop from the temple at Old Uppsala. This passage also reveals an unexpectedly subtle historical logic, in which different places and cultures took architectural leadership at different times. It was only in earliest antiquity that Swedish-Gothic-Atlantean architecture could be influential in the Mediterranean. At any other moment, the formal impulses would have moved the other direction, as was evident in the basically classical nature of Rudbeck's own designs and the many contemporary buildings in Suecia antiqua.

Rudbeck's play on 'Uppsala' and 'öppen sal' itself serves as evidence of the antiquity of the place and the temple, and of its importance for classical culture in the Mediterranean. Observing that the word 'sala' (room) is standard 
in Italian architectural terminology but not found in Vitruvius, he supposes that it was introduced to Italy by the Goths, who reached Rome after Vitruvius wrote. In this way, the far north provided not only the forms of classical architecture, but also part of the accompanying terminology.

Rudbeck's conclusions are exceptionally tendentious, even within the context of the partisan debates over the Goths and other lineages. Yet, many of his points are largely consistent with other arguments about the Goths. The date ' 246 after the flood', given by Johannes Magnus and in the view of the church in Suecia antiqua, must also place it before or at least in the early stages of ancient building. (Here, however, there is no claim that the building was a forerunner of Roman architecture.) This is complicated by the multiple chronological systems in play. Rudbeck shifts constantly from Year of the World (Anno Mundi), to Year of the Lord (Anno Domini; AD ), to Post-Flood. These markers are predicated on a biblical scheme of history, but the events he describes, and the objects and buildings he associates with them, are drawn from Greco-Roman and Nordic myth and history. All were equally valid, and had to be reconciled and consolidated within one vision of world history. ${ }^{54}$

Even within the context of seventeenth-century history writing, Rudbeck's arguments are extreme in many respects, and his findings generated wildly different responses. In 1674, before the first volume of Atlantica was published, Lorenzo Magalotti, a Florentine dignitary visiting Sweden, dismissed his theories about the significance of the church at Old Uppsala. ${ }^{55}$ Leibniz read the book with interest, but was nonetheless quite critical. ${ }^{56}$ Although hardly recognized, however, a strand of Rudbeckian thought thrived throughout the eighteenth and into the nineteenth century. ${ }^{57}$

Although his results were deeply polemical and his conclusions essentially unique, Rudbeck's methods were not unusual. His conflation of various traditions and peoples was common, although he was perhaps unique in the extent to which he did so. His basically philological approach of exploring the relations and mutations of place names, of relating passages from ancient authors to locally observable topography, and so on, were the same ones employed by virtually every other writer on the topic. Likewise, his reliance on ancient texts, the traditional purview of academic historians, in conjunction

54 For an introduction to the problem of chronology and its representation, see Rosenberg D. and Grafton A., Cartographies of Time: A History of the Timeline (Princeton: 2010).

55 Magalotti Lorenzo, Sverige under år 1674 ed. C.M. Stenbock (Stockholm: 1912) 68.

$5^{6}$ Eriksson, Rudbeck 427-430.

57 See the forthcoming extended studies by Bernd Roling and Bernhard Schirg. 
with antiquarian materials, was comparable to contemporary developments in historical methodology elsewhere. ${ }^{58}$

\section{6}

\section{Conclusion}

Pointing to ancient buildings and ruins as evidence of earlier grandeur was hardly a new. It was articulated already in the fourteenth century, when Petrarch bemoaned Rome's decay. It was conveniently formulated in the aphorism 'Roma quanta fuit ipsa ruina docet' ('as Rome once was, its ruins demonstrate'), which gained currency by the 1530s, when Maarten van Heemskerck wrote it on his drawing of the Septizodium of Septimius Severus (ca. 15331535) and Sebastiano Serlio included it on the title page of his Third Book of Architecture (1540).

Heemskerck's and Serlio's interests in the Roman ruins were primarily architectural, to unlock the secrets of the ancients and exploit them in modern projects. Both Dahlbergh and Rudbeck shared these interests, but for the latter, especially, they were secondary to his larger thesis. He sought architectural evidence to prove an essentially imaginary history, and one so fabulous that it must be understood as a kind of poetic vision. His history of architecture, and material evidence more generally, is fundamentally embedded in a more comprehensive historical method that adopts any available evidence in a larger argument that cannot easily be encompassed within conventional understandings of antiquarianism. This informs his analysis of architecture, so that it is adapted to linguistic or other evidence. For instance, his argument that the church at Old Uppsala was the Temple of Poseidon on Atlantis, and thus the starting point for classical architecture, is to some extent complementary to his arguments that the Runic alphabet gave rise to the Greek, and that the Gothic/ Norse gods were transformed into the Greco-Roman gods. His suggestion that the Goths introduced the word 'sala' to Italy brings these strands together in a linguistic-architectural unity emblematic of his work. Although architecture is less central to his study, Verelius's notes on the church at Old Uppsala are likewise embedded within a literary/linguistic context.

This fusion of different strands of textual and material evidence was both typical of seventeenth-century scholarship and radically modern. It was typical of contemporary encyclopedic scholarship in that it presumes a nearly

58 Momigliano A., "Ancient History and the Antiquarian", Journal of the Warburg and Courtauld Institutes 13 (1950) 285-315; Haskell F., History and its Images. Art and the Interpretation of the Past (New Haven - London: 1993). 
universal knowledge, and encompasses many different areas that would eventually become separate fields of inquiry, such as linguistics, the history of architecture, archaeology, and geography, among others. ${ }^{59}$ It was very progressive in that Rudbeck, Verelius, and the State Board of Antiquities were all eager to bring together text and object on equal terms in pursuit of a larger historical narrative decades before scholars elsewhere. ${ }^{60}$ This approach has also been recognized in Piranesi's writing and publishing, with a similar polemical quality. His employment of a huge range of historical evidence has been identified as the locus of his novelty. ${ }^{61}$ However, Rudbeck's historical scope and essentially universal methodology were unmatched, before or since.

\section{Bibliography}

\section{Sources}

Adam of Bremen, Gesta Hammaburgensis ecclesiae pontificum, ed. G. Waitz (Hannover: 1876), trans. F.J. Tschan as History of the Archbishops of Hamburg-Bremen (New York: 1959).

del Castillo Julian, Historia de los reyes godos que vinieron dela Scitia de Europa, contra el Imperio Romano, y a España: y la succession dellos hasta el Catholico y potentissimo don Philippe segundo Rey de España (Burgos, Philippe de Iunta: 1582).

Dahlbergh Erik, Suecia antiqua et hodierna (Stockholm, n.p.: 1715).

Ericus Olai, Chronica regni Gothorum, 2 vols., ed. E. Heuman and J. Öberg (Stockholm: 1993-1995).

Magnus Johannes, De omnibus gothorum sueonumque regibus (Rome, Ioannes Maria de Viottis: 1554).

Magnus Olaus, Historia de gentibus septentrionalibus (Rome, Ioannes Maria de Viottis: 1555), trans. P. Fisher and H. Higgens (London: 1996).

Rudbeck Olaus, Atland eller Manheim (Uppsala, Henricus Curio: 1675-1702; repr. ed. Axel Nelson, Uppsala: 1937-1939).

Rudbeck Olaus, Campus elysius (Uppsala, n.p.: 1701-1702).

59 See inter alia Kelley D.R. (ed.), History and the Disciplines. The Reclassification of Knowledge in Early Modern Europe (Rochester, NY: 1997).

6o Momigliano, "Ancient History and the Antiquarian" identifies Bianchini Francesco, La Istoria Universale provata con monumenti e figurata con simboli degli antichi (Rome, Antonio de Rossi: 1697), as the first book to argue specifically against the use of textual evidence alone.

61 Monferini A., "Le 'Antichità Romane', fulcro della vizione archaeologica del Piranesi”, in Resch R. (ed.), Piranesi. Antichità Romane. Vedute di Roma (Milan: 2000) 19-20. 
Saxo Grammaticus, Gesta Danorum, 2 vols, ed. J. Olrik and H. Ræder (Copenhagen: 1931-1957).

Schefferus Ioannes, Upsalia, cuius occasione plurima in religione, sacris, festis [...] illustrantur (Uppsala, Henricus Curio: 1666).

Verelius Olaus, Hervarar saga på Gammal Götska med Olai Vereli uttolkning och notis (Uppsala, Henricus Curio: 1672).

Verelius Olaus, Manuductio compendiosa ad runographiam Scandicam antiquam, recte intelligendam (Uppsala, Henricus Curio: 1675).

Worm Olaus, Runir seu Danica literatura antiquissimavulgo Gothica dicta (Copenhagen, Melchior Martzan: 1636).

Worm Olaus, Danicorum monumentorum libri sex (Copenhagen, Joachim Moltke: 1643).

\section{Scholarly Literature}

Eriksson G., The Atlantic Vision. Olaus Rudbeck and Baroque Science (Canton, MA: 1994).

Eriksson G., Rudbeck 1630-1702: liv, lärdom, dröm i barockens Sverige (Stockholm: 2002).

Geary P., "Europe of Nations or the Nation of Europe: Origin Myths Past and Present", Revista Lusófona de Estudos Culturais / Lusophone Journal of Cultural Studies 1 (2013) $36-49$.

Goffart W., The Narrators of Barbarian History (A.D. 550-80o): Jordanes, Gregory of Tours, Bede, and Paul the Deacon (Princeton: 1988).

Johannesson K., The Renaissance of the Goths in Sixteenth-Century Sweden. Johannes and Olaus Magnus as Politicians and Historians, trans. J. Larson (Berkeley - Los Angeles: 1991).

Haskell F., History and its Images. Art and the Interpretation of the Past (New Haven London: 1993).

Magnusson B., Att illustrera fäderneslandet: en studie i Erik Dahlbergs verksamhet som tecknare (Uppsala: 1986).

Magnusson B. - Nordin J., Drömmen om stormakten. Erik Dahlberghs Sverige (Stockholm: 2015).

Momigliano A., "Ancient History and the Antiquarian", Journal of the Warburg and Courtauld Institutes 13 (1950) 285-315.

McKeown S., "Recovering the Codex Argenteus: Magnus Gabriel de la Gardie, David Klöcker Ehrenstrahl and Wulfila's Gothic Bible”, Lychnos (2005) 9-28.

Neville K., "Gothicism and Early Modern Historical Ethnography", Journal of the History of Ideas 70 (2009) 213-234. 
Neville K., "The Land of the Goths and Vandals. The Visual Presentation of Gothicism at the Swedish Court, 1550-1700", Renaissance Studies 27 (2013) 395-408.

Norris M., A Pilgrimage to the Past.Johannes Bureus and the Rise of Swedish Antiquarian Scholarship, 1600-1650 (Lund: 2016).

Santini C., ed., I fratelli Giovanni e Olao Magno. Opera e cultura tra due mondi (Rome: 1999).

Schmidt-Voges I., De antiqua claritate et clara antiquitate Gothorum. Gotizismus als Identitätsmodell im frühneuzeitlichen Schweden (Frankfurt: 2004).

Schück H., Kgl. Vitterhets historie och antikvitets akademien: dess förhistoria och historia, 8 vols. (Stockholm: 1932-1944).

Skovgaard-Petersen K., Historiography at the Court of Christian IV. Studies in the Latin Histories of Denmark by Johannes Pontanus and Johannes Meursius (Copenhagen: 2002).

Søby Christensen A., Cassiodorus, Jordanes and the History of the Goths. Studies in a Migration Myth (Copenhagen: 2002). 